\title{
Tolerance of some scab-resistant apple cultivars to the rosy apple aphid, Dysaphis plantaginea
}

\author{
Marcos Miñarro*, Enrique Dapena \\ Servicio Regional de Investigación y Desarrollo Agroalimentario (SERIDA), Apdo. 13, E-33300 Villaviciosa, Asturias, Spain
}

Received 24 November 2006; received in revised form 26 June 2007; accepted 6 July 2007

\begin{abstract}
Rosy apple aphid (RAA), Dysaphis plantaginea Passerini (Homoptera: Aphididae), is a major apple pest that is normally controlled by insecticide sprays. The use of tolerant cultivars to reduce damage of this aphid would contribute to a non-chemical crop protection. This study evaluated the susceptibility of nine scab-resistant apple cultivars ('Dayton', 'Freedom', 'Galarina', 'GoldRush', 'Jonafree', 'Liberty', 'Priscilla', 'Redfree' and 'Williams' Pride') to RAA. Greenhouse trials and field observations were conducted for 2 years. Significant differences were observed among cultivars in aphid abundance and damage level 21 days after an infestation in the greenhouse. 'GoldRush' and 'Galarina' did not show typical leaf-rolls induced by RAA and were considered tolerant to this aphid species. Some cultivars showed low susceptibility while the cultivars 'Jonafree' and 'Redfree' turned out to be highly susceptible. Aphid abundance and damage levels were positively correlated. Field surveys confirmed greenhouse results. Growing cultivars resistant to scab and tolerant or only slightly susceptible to RAA would reduce pesticide use and increase opportunities for sustainable apple production. (C) 2007 Elsevier Ltd. All rights reserved.
\end{abstract}

Keywords: Goldrush; Galarina; Malus domestica; Scab resistance; Tolerance; $V_{f}$ gene

\section{Introduction}

Rosy apple aphid (RAA), Dysaphis plantaginea Passerini (Homoptera: Aphididae), is a common apple pest that causes leaf-rolling and shoot distortion. When the infestation is high, this aphid reduces the commercial value of the yield because fruits remain smaller and deformed. Control of RAA relies primarily on pesticide sprays. Since naturally occurring enemies are not efficient in controlling this aphid (Miñarro et al., 2005) and since resistance to aphicides has been reported (Delorme et al., 1998), new strategies, such as cultivar resistance, seem necessary for the sustainable control of RAA (Miñarro and Dapena, 2005).

One aim of sustainable production is to reduce the impact of collateral effects due to pesticides (Cross, 2002; Weibel and Häseli, 2003). Resistant plants are a promising alternative for growing apple, Malus domestica (Borkh.), with lower inputs of pesticide. Many breeding programs

\footnotetext{
${ }^{*}$ Corresponding author. Tel.: + 34985890066 ; fax: + 34985891854 .

E-mail address: mminarro@serida.org (M. Miñarro).
}

have been developed worldwide to improve the resistance to apple scab caused by Venturia inaequalis (Cke.) Wint. (Crosby et al., 1992; Brown and Maloney, 2003). At least six genes for resistance to scab have been described, but most of the breeding programmes have concentrated on the $V_{f}$ gene derived from Malus floribunda 821 (Brown and Maloney, 2003). The Institut National de la Recherche Agronomique (INRA) in Angers (France) released the cultivar named 'Florina' (Lespinasse et al., 1985), which apart from having the $V_{f}$ gene and being only slightly susceptible to fire blight is resistant to RAA (Rat-Morris, 1993).

Rat-Morris (1993) described the mechanism of resistance to RAA of the cultivar 'Florina'. This cultivar is considered tolerant to this aphid because it did not show the typical deformations that RAA causes in susceptible plants (longitudinal rolls caused by the leaf to roll downwards along its length (Forrest and Dixon, 1975)). In addition, there is an antibiosis effect as the aphid is less fecund and exhibits a high mortality when fed on 'Florina'. These resistance mechanisms, as well as the resistance to scab, 
seem to have been inherited from M. floribunda 821 (Rat-Morris and Lespinasse, 1995). Thus, other cultivars with the $V_{f}$ system possibly have also inherited the resistance to RAA from $M$. floribunda 821 .

Since apple scab is a disease of major concern in most apple-producing regions (Grove et al., 2003), at present numerous scab-resistant cultivars have been developed by various organizations. This study aimed at testing differences in the susceptibility level to RAA in nine scabresistant apple cultivars ('Dayton', 'Freedom', 'Galarina', 'GoldRush', 'Jonafree', 'Liberty', 'Priscilla', 'Redfree' and 'Williams' Pride'). If those cultivars display a tolerant response to RAA, their use would solve two main phytosanitary problems (scab and RAA) facilitating a non-chemical crop protection.

\section{Material and methods}

The susceptibility to RAA was examined in greenhouse conditions in May-June 2003 and 2005 and in field orchards in spring 2004 and 2005 in Asturias, NW Spain $\left(43^{\circ} 30^{\prime} \mathrm{N}, 5^{\circ} 30^{\prime} \mathrm{W}\right)$.

\subsection{Plant material in the greenhouse test}

The test was carried out on the following cultivars: 'Dayton', 'Freedom', 'Galarina', 'GoldRush', 'Jonafree', 'Liberty', 'Priscilla', 'Redfree' and 'Williams' Pride'. All of these cultivars were derived from the same cross (M. floribunda $821 \times$ 'Rome Beauty') $\times(M$. floribunda $821 \times$ 'Rome Beauty'), from which these cultivars obtained the $V_{f}$ gene of resistance to scab. Specifically, 'Dayton' (Korban et al., 1988), 'GoldRush' (Crosby et al., 1994), 'Jonafree' (Dayton et al., 1979), 'Priscilla' (Williams et al., 1972), 'Redfree' (Williams et al., 1981) and 'Williams' Pride' (Janick et al., 1988) have been developed by a cooperative apple breeding program among Purdue, Rutgers and Illinois Universities (USA). 'Freedom' (Lamb et al., 1985) and 'Liberty' (Lamb et al., 1979) have been developed by the New York State Agriculture Experiment Station (USA), and the INRA in Angers (France) developed 'Galarina' (Khanizadeh et al., 2003).

In addition, 'Golden Delicious' and 'Florina' were respectively the susceptible and the resistant controls. The cultivars were grafted on M7 rootstocks and potted. Eight plants of each cultivar were placed in a greenhouse when new shoots were about $25 \mathrm{~cm}$. Then plants were disinfested with rotenone and a Bacillus thuringiensis-based insecticide. A completely randomized experimental design was used. Plants were properly irrigated and fertilized during the experimental period.

These nine cultivars were evaluated in 2003. After the results of 2003, three of these cultivars ('Galarina', 'GoldRush' and 'Liberty') were also evaluated in 2005 following the same procedure used in 2003.

\subsection{Aphids}

Aphids were field-collected from different colonies in different apple orchards to capture a large genetic variability. Individuals from each colony were reared separately on susceptible apple plants. Thus, several distinct populations of RAA were maintained in the laboratory. The experimental plants were infested with six adult apterous females that were carefully placed on the first expanded leaf with the help of a small paintbrush. Each aphid placed on the same plant came from a different population. Aphid movement from one plant to another was prevented by putting the pots in dishes with water. There were no overlapping branches. Alates forming on apple did not constitute a problem because they are not able to feed or reproduce on apple since RAA is a dioecious species. To make sure that the aphids stayed on the principal shoot, secondary shoots were periodically pruned.

\subsection{Level of infestation and damage}

As previous work showed that 3 weeks is time enough to see differences in susceptibility (Dapena and Miñarro, 2001; Miñarro and Dapena, 2004), observations were made at the end of the experiment, 21 days following infestation. Moreover, Forrest and Dixon (1975) showed that susceptible plants display leaf-rolls in $24 \mathrm{~h}$. Shoot deformation was recorded using a scale from 0 to 5 : $0=$ no damage; $1=$ leaf slightly curled at the edge; $2=$ leaf slightly curled longitudinally; $3=$ typical RAA leaf rolling; $4=2-5$ typically rolled leaves; and $5=$ more than 5 typically rolled leaves. Plants exhibiting damage levels 0,1 or 2 were considered as tolerant while plants with typically rolled leaves were considered as low or highly susceptible depending on the level of damage. Aphid abundance was described by 6 indices: $0=$ no aphids; $1=1-5$ aphids; $2=6-25$ aphids; $3=26-125$ aphids; $4=126-625$ aphids; and $5=$ more than 625 aphids.

\subsection{Field surveys}

Evaluation of apple cultivars in the field has practical limitations imposed on ideal experimental design. The susceptibility to RAA was surveyed in field orchards in all the cultivars tested in the greenhouse. Nevertheless, the replication may be a little dubious when cultivars are observed in different orchards with different ages.

In 2004, all the cultivars were surveyed in field orchards. 'Dayton', 'Freedom', 'Jonafree', 'Liberty', 'Prima' (which was used as susceptible control), 'Priscilla' and 'Redfree' were randomly distributed in an experimental orchard in three groups of two trees of each cultivar. Eighty-four trees of 'GoldRush' and 28 trees of 'Florina' (used as resistant control) were present in the same orchard. This orchard was established in 2003. Finally, three trees of 'Galarina', M. floribunda 821 and 'Williams' Pride' were present in 
another orchard established in 2001. All of these trees were observed for RAA damage in late May. Damage level was categorized in the same manner as in the greenhouse experiment.

In spring 2005, the level of damage was recorded in all the cultivars in the same orchards as 2004 .

\subsection{Data analysis}

Cultivar differences in aphid abundance and plant damage were analyzed by Kruskal-Wallis tests. Mann-Whitney $U$-tests were used to establish groups of cultivars using the Bonferroni adjustment for multiple tests $(\alpha=0.05 /$ number of pairwise comparisons). The relationship between abundance of aphids and damage level was analyzed by Spearman correlations.

\section{Results and discussion}

\subsection{Greenhouse}

In 2003, damage varied significantly among cultivars at the end of the experiment in the greenhouse $\left(\chi^{2}=58.20\right.$;

A

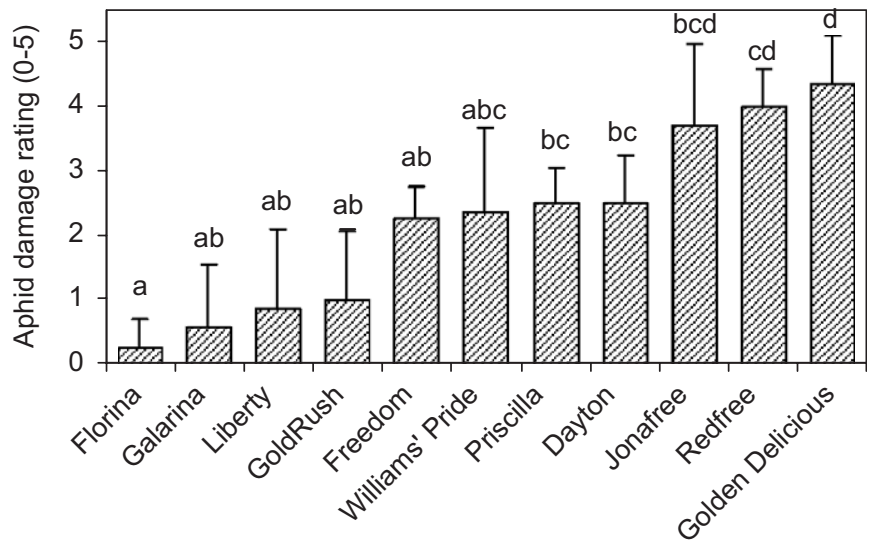

B

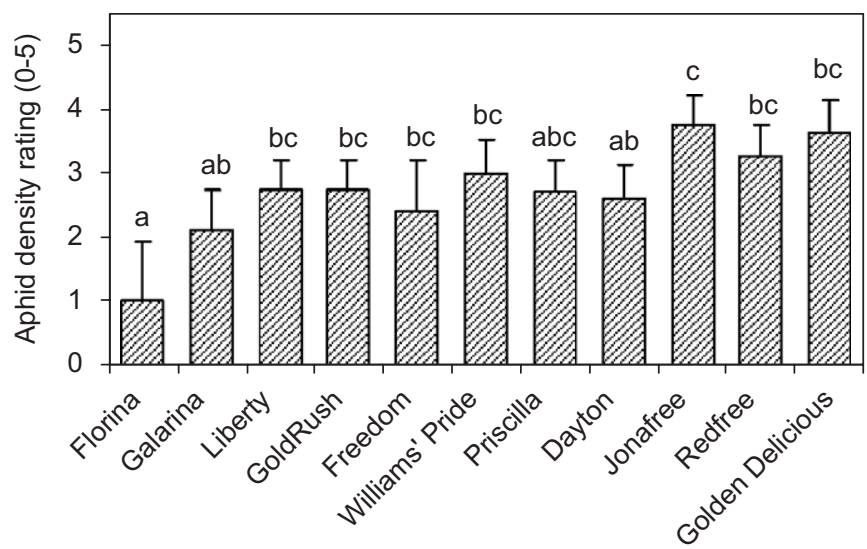

Fig. 1. Average levels of damage (A) and aphid abundance (B) exhibited by the cultivars 21 days after infestation with six aphids in the greenhouse in 2003. Error bars are standard deviations. Bars with the same letter are not significantly different using the Bonferroni adjustment. d.f. $=10 ; P<0.001)($ Fig. 1A). Cultivars showed a gradient in the damage level from the tolerant 'Florina' to the most susceptible 'Golden Delicious'. Groups of cultivars could not be statistically established using the Bonferroni adjusted $\alpha=0.0009$ (0.05/55 pairwise comparisons). However, three groups of cultivars could be roughly established in regard to aphid damage level. Firstly, 'Florina', 'Galarina', 'Liberty' and 'GoldRush' were least affected by RAA, with each having a damage level less than 1 . 'Galarina' and 'GoldRush' were considered tolerant to RAA since none of the plants showed the typical leaf-roll caused by this aphid. Although 'Liberty' generally performed well in 2003, one plant out of the eight did exhibit a typical leaf-roll corresponding to damage level 3. Secondly, 'Dayton', 'Freedom', 'Priscilla' and 'Williams' Pride' exhibited an intermediate level of damage. Finally, 'Golden Delicious', 'Jonafree' and 'Redfree' showed very high susceptibility to RAA. The abundance of aphids at the end of the experiment also varied among cultivars $\left(\chi^{2}=51.06 ;\right.$ d.f. $\left.=10 ; P<0.001\right)($ Fig. $1 \mathrm{~B})$.

In 2005, the three cultivars that showed tolerance or very low susceptibility in 2003 ('Galarina', 'GoldRush' and 'Liberty') were evaluated again to confirm the results

A

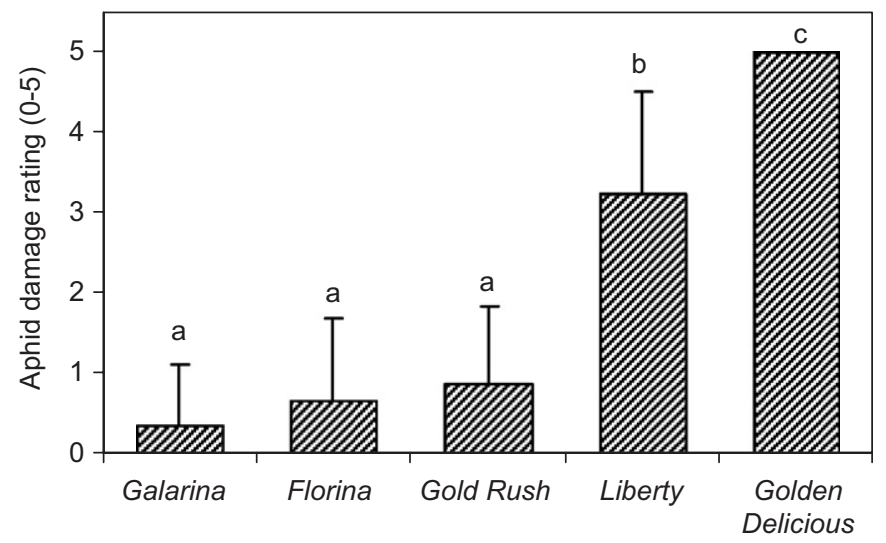

B

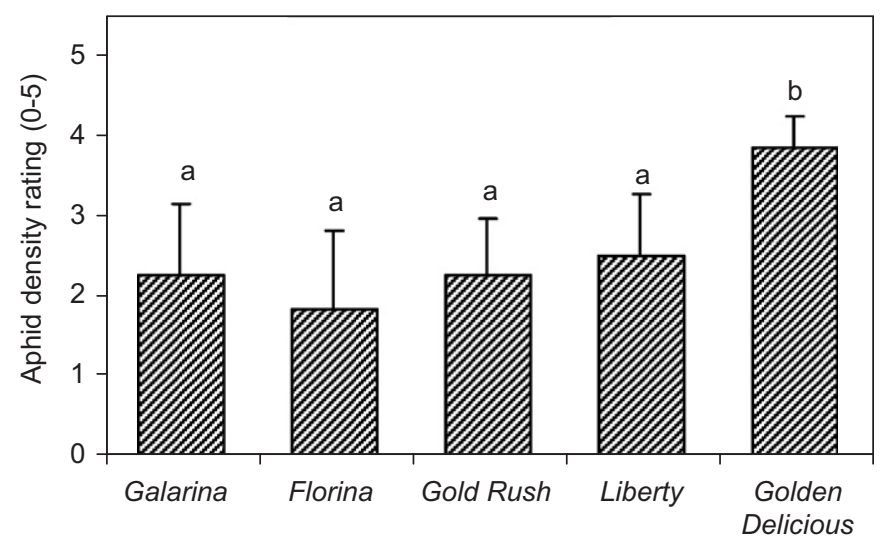

Fig. 2. Average levels of damage (A) and aphid abundance (B) exhibited by the cultivars 21 days after infestation with six aphids in the greenhouse in 2005. Error bars are standard deviations. Bars with the same letter are not significantly different using the Bonferroni adjustment. 

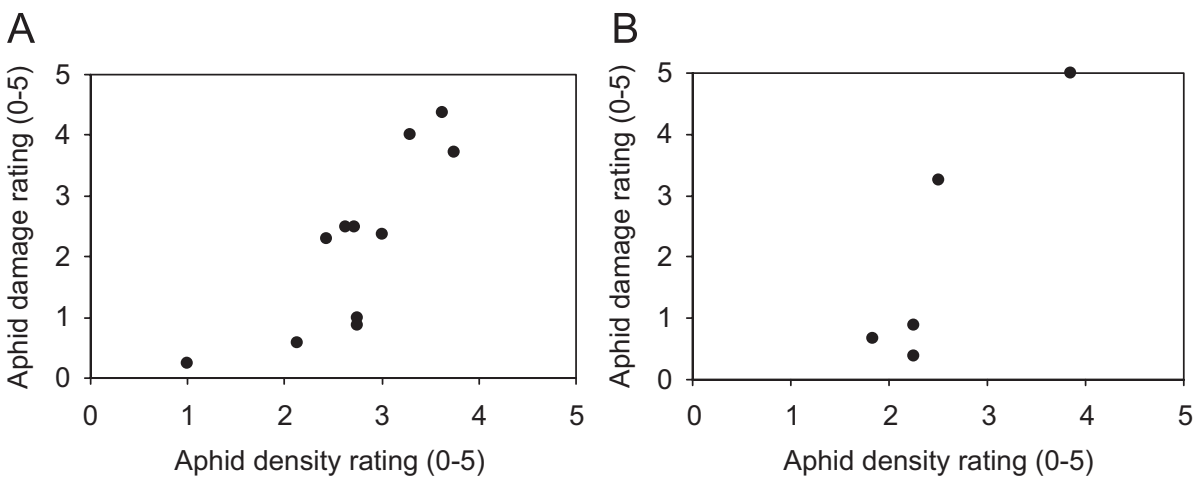

Fig. 3. Relationship between aphid abundance and damage exhibited by the cultivars after 21 days following infestation in the greenhouse in 2003 (A) and 2005 (B).

(Fig. 2). There were significant differences in both damage $\left(\chi^{2}=26.23 ;\right.$ d.f. $\left.=4 ; P<0.001\right)$ and aphid abundance $\left(\chi^{2}=16.82 ;\right.$ d.f. $\left.=4 ; P<0.01\right)$. Groups were established using $\alpha=0.005$ ( $0.05 / 10$ pairwise comparisons). 'Galarina' and 'GoldRush' showed a tolerant response similar to 'Florina' in both aphid abundance and damage level. However, several plants of 'Liberty' showed the typical leaf-roll corresponding to damage level 3. The susceptible control 'Golden Delicious' exhibited very high infestation and damage.

Greenhouse results showed that two out of the nine scabresistant cultivars evaluated, 'Galarina' and 'GoldRush', were found to be tolerant to RAA, since both cultivars did not show leaf-rolls. 'Galarina' is from a cross between 'Gala' and 'Florina' (Khanizadeh et al., 2003). Since the tolerance of 'Florina' to RAA is heritable in a high percentage (Dapena and Miñarro, 2001; Miñarro and Dapena, 2004), the tolerant response displayed by 'Galarina' is a trait directly inherited from 'Florina'. On the other hand, 'Florina' inherited the resistance to RAA from $M$. floribunda 821 (Rat-Morris and Lespinasse, 1995). It seems reasonable to assume that 'GoldRush' had also inherited tolerance of RAA feeding from $M$. floribunda 821 .

Aphid abundance was positively correlated with damage in $2003\left(r_{s}=0.767\right.$; d.f. $\left.=10 ; P<0.01\right)$ (Fig. 3$)$, that is, larger numbers of aphids led to more damage. This trend was also observed in 2005 , although the relationship was not significant due to the low number of cultivars tested $\left(r_{s}=0.821 ;\right.$ d.f. $\left.=4 ; P=0.089\right)$.

\subsection{Field}

In May 2004, 'Florina', 'Galarina', 'GoldRush', 'Liberty', 'Priscilla', 'Williams' Pride' and M. floribunda 821 did not show leaf-rolls (Fig. 4A). However, 'Dayton', 'Freedom', 'Jonafree', 'Redfree' and the susceptible control 'Prima' showed severe aphid damage that year. Results in 2005 were similar to those of 2004: no damage was observed on 'Florina', 'Galarina', 'GoldRush', 'Liberty', 'Priscilla', 'William's Pride' or M. floribunda 821 (Fig. 4B). On the other hand, 'Dayton', 'Freedom', 'Jonafree', 'Redfree' and 'Prima' showed severe damage.
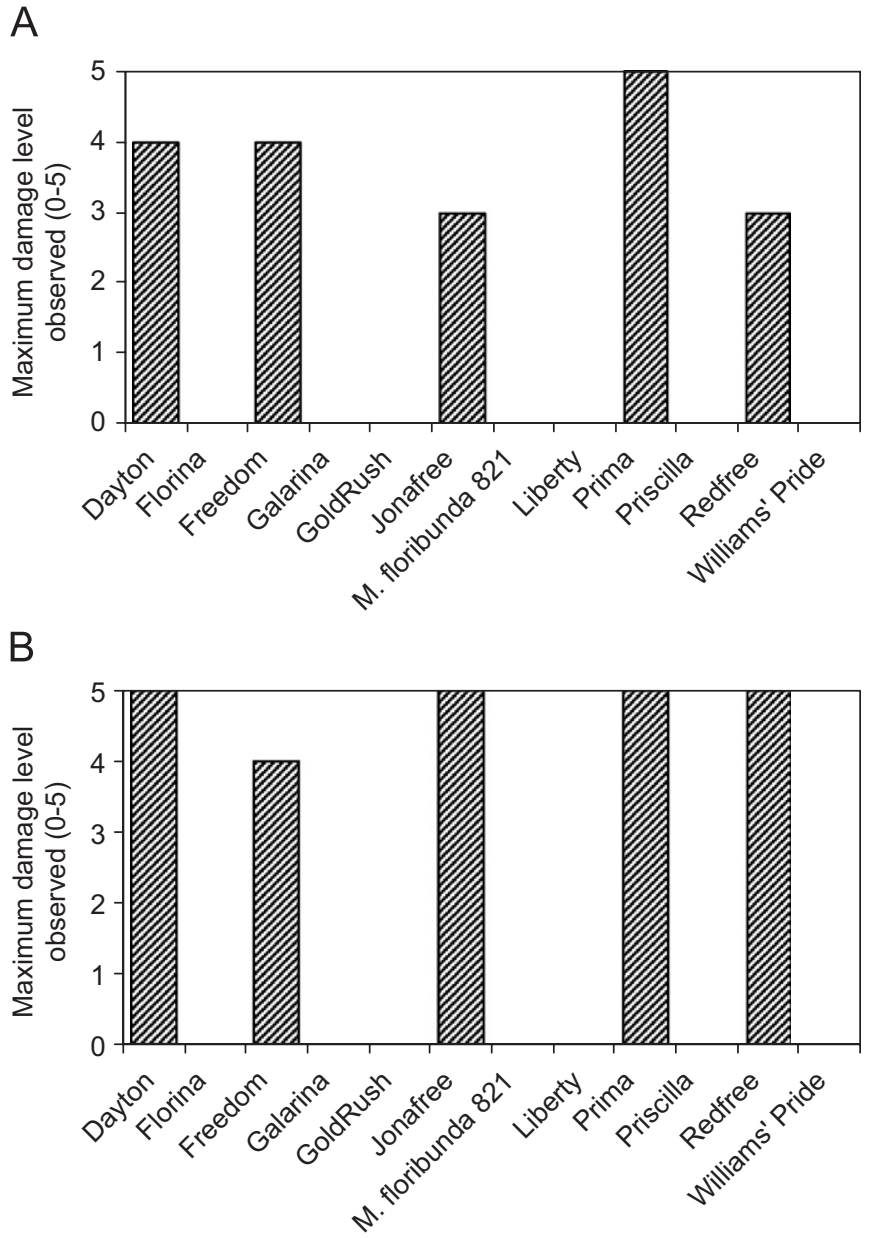

Fig. 4. Maximum damage observed in each cultivar in 2004 (A) and in 2005 (B) in the field.

Field surveys confirmed greenhouse results: 'Galarina' and 'GoldRush' were tolerant to RAA, while 'Jonafree' and 'Redfree' were susceptible. Among the other group that exhibited a low or an intermediate level of damage in the greenhouse, some cultivars ('Dayton' and 'Freedom') appeared susceptible and some others ('Liberty', 'Priscilla' and 'William's Pride') did not suffer aphid infestation or damage. Positive correlation between damage in greenhouse 
and field studies has been observed previously (Dapena and Miñarro, 2001). Moreover, aphid colonies were not developed on M. floribunda 821 in the field, but further studies should be performed to confirm and characterize the resistance.

All of the tested cultivars obtained the $V_{f}$ gene of resistance to scab from $M$. floribunda 821. Although the $V_{f}$ gene and the tolerance to RAA are inherited independently (Miñarro and Dapena, 2004), some cultivars ('Florina', 'Galarina' and 'GoldRush') are also tolerant to this aphid. An exploration of the response to RAA of other descendants of $M$. floribunda 821 could allow identification of other resistant cultivars.

The results showed that some cultivars with the $V_{f}$ gene of scab resistance are also tolerant or have reduced susceptibility to RAA. Therefore, these cultivars are a non-pesticide alternative in pest management with obvious economical and ecological advantages. Controlling two of the major apple pests without pesticides is an important contribution to the development of sustainable production.

\section{Acknowledgments}

We thank R. Barros and G. Fernández-Mata for practical assistance, J.-L. Hemptinne and Y. Lespinasse for helpful comments on an earlier draft of the manuscript, and INRA and J.-M. Lespinasse for kindly providing us with the hybrid X4982 (currently 'Galarina'). This research has been financially supported by the Project INIA RTA-02-50-C2.

\section{References}

Brown, S.K., Maloney, K.E., 2003. Genetic improvement of apple: breeding, markers, mapping and biotechnology. In: Ferree, D.C., Warrington, I.J. (Eds.), Apples: Botany, Production and Uses. CAB International, Oxon, UK, pp. 31-60.

Crosby, J.A., Janick, J., Pecknold, P.C., Korban, S.S., O'Connon, P.A., Ries, S.M., Goffreda, J., Voordeckers, A., 1992. Breeding apples for scab resistance: 1945-1990. Fruit Var. J. 46 (3), 145-166.

Crosby, J.A., Janick, J., Pecknold, P.C., Goffreda, J., Korban, S.S., 1994. 'GoldRush' apple. HortScience 29 (7), 827-828.

Cross, J.V., 2002. Guidelines for integrated management of pome fruits in Europe. IOBC/WPRS Bull. 25 (8), 45pp.

Dapena, E., Miñarro, M., 2001. Evaluation of the tolerance to the rosy apple aphid, Dysaphis plantaginea (Pass.), in descendants of the crossing 'Raxao' $\times$ 'Florina'. IOBC/WPRS Bull. 24 (5), $247-251$.

Dayton, D.F., Mowry, J.B., Williams, E.B., Janick, J., Emerson, F.H., Hough, L.F., Bailey, C., 1979. 'Jonafree' apple. HortScience 14, $551-552$.

Delorme, R., Auge, D., Touton, P., Vergnet, C., Villatte, F., 1998. La résistance des pucerons aux insecticides. Enquête 1997. In: Proceedings of the $1^{\text {er }}$ Colloque transnational sur les luttes biologiques, intégrée et raisonnée. Bilan et perspectives au regard d'expériences régionales et européennes, Lille, France, pp. 375-384.

Forrest, J.M.S., Dixon, A.F.G., 1975. The induction of leaf-roll galls by the apple aphids Dysaphis devecta and D. plantaginea. Ann. Appl. Biol. 81, 281-288.

Grove, G.G., Eastwell, K.C., Jones, A.L., Sutton, T.B., 2003. Diseases of apple. In: Ferree, D.C., Warrington, I.J. (Eds.), Apples: Botany, Production and Uses. CAB International, Oxon, UK, pp. 459-488.

Janick, J., Emerson, F.H., Pecknold, P.C., Crosby, J.A., Korban, S.S., Dayton, D.F., 1988. 'Williams' Pride' apple. HortScience 23 (5), 928-930.

Khanizadeh, S., Laurens, F., Lespinasse, Y., Groleau, Y., Cousineau, J., Carisse, O., DeEll, J., 2003. 'Galarina' apple. HortScience 38 (3), $477-478$.

Korban, S.S., Janick, J., Williams, E.B., Emerson, F.H., 1988. 'Dayton' apple. HortScience 23 (5), 927-928.

Lamb, R.C., Aldwinckle, H.S., Way, R.D., Terry, E.D., 1979. 'Liberty' apple. HortScience 14, 757-758.

Lamb, R.C., Aldwinckle, H.S., Terry, E.D., 1985. 'Freedom', a diseaseresistant apple. HortScience 20, 774-775.

Lespinasse, Y., Olivier, J.M., Lespinasse, J.M., LeLezec, M., 1985. 'Florina-Quérina' ${ }^{\circledR}$ : la résistance du pommier à la tavelure. Arboric. Fruit. 378, 43-47.

Miñarro, M., Dapena, E., 2004. Inheritance of the tolerance to the rosy apple aphid of the cv. 'Florina'. Acta Hortic. 663, 261-264.

Miñarro, M., Dapena, E., 2005. Sustainable control of the rosy apple aphid Dysaphis plantaginea. IOBC/WPRS Bull. 28 (7), 113-117.

Miñarro, M., Hemptinne, J.-L., Dapena, E., 2005. Colonization of apple orchards by predators of Dysaphis plantaginea: sequential arrival, response to prey abundance and consequences for biological control. Biol. Control 50 (3), 403-414.

Rat-Morris, E., 1993. Development of the rosy apple aphid Dysaphis plantaginea Pass. on a tolerant apple cultivar 'Florina'. IOBC/WPRS Bull. 16 (5), 91-100.

Rat-Morris, E., Lespinasse, Y., 1995. Pommier: la résistance au puceron cendré associée à la résistance à la tavelure. Phytoma-La Défense des vègétaux 471, 15-17.

Weibel, F., Häseli, A., 2003. Organic apple production —with emphasis on European experiences. In: Ferree, D.C., Warrington, I.J. (Eds.), Apples: Botany, Production and Uses. CABI, Oxon, UK, pp. 551-584.

Williams, E.B., Janick, J., Emerson, F.H., Dayton, D.F., Mowry, J.B., Hough, L.F., Bailey, C., 1972. 'Priscilla', a fall red apple with resistance to apple scab. Fruit Var. J. 26 (2), 34-35.

Williams, E.B., Janick, J., Emerson, F.H., Dayton, D.F., Hough, L.F., Bailey, C., 1981. 'Redfree' apple. HortScience 16 (6), 798-799. 